\title{
The Effect of Internet Slack on Learning Performance
}

\author{
I N Hariwibowo"1 \\ ${ }^{1}$ Universitas Atma Jaya Yogyakarta, Jl. Babarsari No. 43, Yogyakarta 55281 \\ E-mail: novianto.wibowo@uajy.ac.id ${ }^{1}$
}

Masuk: 2 April 2019, direvisi: 1 Juni 2019, diterima: 2 Juli 2019

\begin{abstract}
Abstrak. Di tengah meluasnya penerapan internet dalam kegiatan pembelajaran, penelitian ini dilakukan untuk menilai dampak penyalahgunaan internet terhadap hasil belajar di kelas. Penelitian terdahulu menunjukkan dampak penggunaan internet yang beragam dan penelitian ini bertujuan untuk menunjukkan konsekuensi penyalahgunaan internet terhadap hasil belajar. Penelitian ini dilakukan pada mahasiswa kelas akuntansi dengan sistem pembelajaran hybrid, di mana pembelajaran dilakukan secara tatap muka di kelas tetapi didukung oleh teknologi $e$ learning. Responden penelitian ini adalah 224 mahasiswa akuntansi. Data diambil dengan menggunakan kuesioner dan 216 kuesioner diproses menggunakan SEM-PLS. Hasil penelitian ini menunjukkan bahwa penyalahgunaan internet tidak memoderasi pengaruh interaksi dan kehadiran sosial terhadap kinerja pembelajaran di kelas. Temuan ini menunjukkan bahwa penyalahgunaan internet bukan faktor yang menurunkan kinerja pembelajaran siswa dan dapat menjadi masukan bagi perancangan konsep e-learning untuk menggunakan internet sebagai media belajar yang interaktif di mana kegiatannya masih dapat dikendalikan.
\end{abstract}

Kata kunci: Internet Slack; Social presence; Social Interaction; Learning Performance

\begin{abstract}
In the midst of the widespread application of the internet in learning activities, this research was conducted to assess the impact of internet abuse on classroom learning outcomes. Published research shows the impact of diverse internet uses and this study aims to show the consequences of internet abuse on learning outcomes. This research was conducted on accounting class students with a hybrid learning system, where learning is done face-to-face in class but is supported by e-learning technology. The respondents of this study were 224 accounting students. Data were taken using questionnaires and 216 questionnaires were processed using SEM-PLS. The results of this study indicate that internet abuse does not moderate the influence of interaction and social presence on classroom learning performance. These findings indicate that internet abuse is not a factor that decreases student learning performance and can be an input for the design of e-learning concepts to use the internet as an interactive learning media where activities can still be controlled.
\end{abstract}

Keywords: Internet Slack; Social presence; Social Interaction; Learning Performance

\section{Introduction}

Internet has become a popular learning media in education. On the e-learning process, internet supports communication between students and teachers. Course material can be distributed any time, so the class activities become efficient and easy through online activities [1]. At this point, internet 
looks great as a learning media. On the other side, the research from Arbaugh [2] shows that there is no difference between traditional way of learning and online learning. This result is supported by Cao and Sakchutchawan [3], there is no different learning performance both from online class and traditional class. Some schools have an online learning program and other schools carry out a learning in the classroom with internet application or hybrid/blended class. However, the research from Ashby et al. [4] indicates that learning performance of the student from online class and hybrid course is better than traditional class. For that case, there are differences of opinion which is better between classroom or internet based course.

Although internet facilitates learning process in the classroom, its usage in the classroom has several problems. In some cases, e-learning implementation is out of the expectation. The students do not use internet as media for class activities but they use it for something that is not relevant with the course in the class [5], [6], [7]. This condition can be called as internet slack or internet abuse [8], [1]. Internet slack steals the students' attention from the class or from the teachers [36].

The problem is not about the internet as a learning media. In facts, social presence and interaction are the important factors in learning process [9], [10], [11]. Learning is about transfer knowledge or information. Teacher and students need to interact. Communication makes the teacher can assess how deep the students understand the lesson. Social presence is one of the elements influencing a student's performance in the learning process because social presence supports the student to absorb the information [24]. In this case, from the previous research, it can be indicated that the internet slack has a potential problem for social presence in the classroom. That the students being distracted to pay attention to the classroom activities is the problem of using internet in the classroom [5], [6], [7].

Internet slack is a problem that can be a barrier for applying technology in the learning. Internet slack is a condition that encourages internet abuse. Research on the abuse of the internet in the learning process has been investigated specifically by Gerow et al. [1]. However, their studies only explain the factors that can affect students to abuse the internet and do not directly assess the effects of the internet slack density in learning outcomes. The question arising from this is that whether there is any effect between internet slack in the learning performance and whether the internet slack becomes a problem for learning performance in the technology era now. Those are the questions arising from these phenomena but there are still some debates on internet benefits in the learning process.

To answer this problem, this research will examine the effect of internet slack on social presence and social interaction that may influence the student's academic success. The study about e-learning is still needed, even though there were several studies on e-learning due to the pressure of technology development [12]. Knowing the impact of internet slack to learning performance is important to evaluate the role of information technology in education [1]. Through this study, the decision makers can design the best way to implement an e-learning process. As the result, the effective collaboration between education and technology can be found.

\section{Theoretical Framework and Hypotheses Development}

\subsection{Social Presence}

Social presence theory comes from social psychological theories and symbolic interactionism [13], [14], [15]. Short et al. [16] first argue that, in the social presence, media contributes to the degree of intimacy. Their researches show that social presence is degree of specificity of other people in a mediated communication and the consequent salience of the interpersonal relationship. Now, social presence appears as a form of effectiveness, efficiency and satisfaction in using of communication media [17]. Specifically, Lowenthal and Wilson [18] states that social presence is people's perception of a person's being real. It means that people set up themselves in the environment and others can perceive them. Social presence arises as a situation when people are emotionally connected in a place [18]. To make the situation of social presence, there are three factors that can affect the social presence. The factors are co-presence, intimacy, and immediacy [14]. Co-presence is related to the subjective experience of being together with others [19], [20]. Intimacy can be defined as the level of 
people taking care, trusting, expressing and making relation with others [16]. Zhang and Oetzel [21] state that immediacy is an individual perception on directness and intensity with others.

Social presence has an important role in the learning process [22], [23], [24]. Social presence supports cognitive and affective objectives of learning by sustained interactions [25]. Without it, students may feel alone and have lower level of affective learning toward the instructor [26], [27]. Social presence comes as an important issue for increasing and improving the effectiveness of learning environments [28]. Social cognitive theory also supports that social presence is a primary factor for social learning [15]. Hence, the following hypothesis is proposed:

$\mathrm{H} 1$ : Social presence positively influences learning performance in the classroom

\subsection{Social Interaction}

Another factor that can improve the learning performance is social interaction. Social interaction is identified with multiplicative reverse of social ties between at least two characters [11]. Social interaction is likewise a concentration of perceivability, mindfulness, and responsibility with others [29], [10], while, another research shows that social presence has positively affected the student's satisfaction in web based learning environments [30], [23].

Like social presence, social interaction is a factor that affects the success of students in the learning process [31]. Interaction makes the lecturer knows about how deep the students understand the course material. Social interaction encourages the formation of collaboration in the learning process so that students are helped in learning [32]. These studies show that social interaction is important in the learning performance, so the hypothesis is:

$\mathrm{H} 2$ : Social interaction positively influences student's learning performance.

\subsection{Internet Slack}

Internet slack is a term used to describe internet usage that is not in accordance with its provisions [1]. This situation can happen in the classroom. Teacher cannot deliver the information effectively if students are not aware of others. Bugeja [9] shows that students can pay attention and get a better performance without laptop or computer in the classroom. Lavoie and Pychyl [33] represent that inability to control the great internet access can disrupt students in the learning process.

The effect of internet slack to learning performance is indirect. In the social presence theory, media has an important role in the success of communication. Media as a communication tool will facilitate interaction between the two parties. In e-learning system, internet will facilitate interaction between teacher and student. Effective communication will have a positive impact on student learning performance. On the other side, the poor communication media utilization will make a bad learning process. In the e-learning classroom, internet slack will disturb the attention and interaction between student and teacher.

From those situations, it can be understood that internet slack has negative impact on the learning process in the classroom. The Internet slack can reduce students' attentiveness in paying attention in the classroom. Hence, the following hypothesis is proposed:

H3: Internet slack negatively moderates the influence of social presence to learning

performance.

Kozuh et al. [10] uses social interaction and social presence to test the effect on student's academic success in online learning class. The result of this study shows that social interaction can facilitate students to be success in their academic, but surprisingly, the result shows that the perceived ease of using the social tools negatively affect the students' success. This problem may appear because of internet slack [1]. From the cases above, using internet in the classroom can make student ignore the teacher and other students [7]. Students can be busy with their internet activity because of cognitive absorption. It will reduce interaction in the learning process.

$\mathrm{H} 4$ : Internet slack negatively moderates the influence of social interaction to learning performance. 


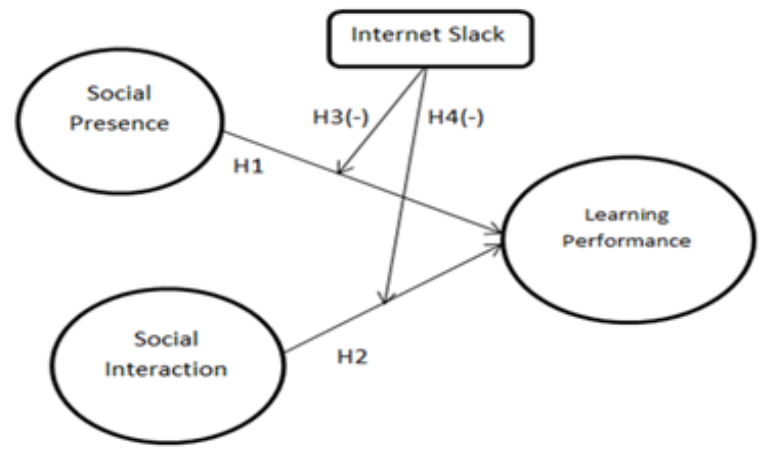

Figure 1. Proposed Research Model Research

\section{Methodology}

\subsection{Research objects and data}

The purpose of this study is to examine whether internet slack affects the classroom conditions that will affect students' learning performance. Learning atmosphere in the classroom will be influenced by social presence and social interaction. To answer this research question, the respondents of this study were from two different majors. The classes used as sample were three consisting Public Sector Accounting classes and two Accounting Information System classes. Students involved in these classes were 224 students. These classes were chosen because the classes were held through face-toface meetings between lecturers and students in which the students were allowed to use internet for supporting the learning activity in the classroom. The questionnaire was distributed in the last meeting. It aimed to make the students experience the learning process that combines face to face learning and internet usage.

\subsection{Operational definition and measurement}

This research examined the effect of social presence and social interaction to the learning performance moderated by internet slack. There were three variables used in this research. Social presence and social interaction were independent variables and learning performance was the dependent one. Based on the previous research, internet slack would reduce the social presence and social interaction. Hence it affected the learning performance so internet slack was a moderating variable.

To develop the previous research, this research adapted operational definition variable from the previous research. Social presence in this research was related to the awareness of the importance of the relationship among people in the classroom [18], [17], [16]. Classroom was a media for communication. Social interaction in this research was related to awareness of the importance of the communication relationship between one student to other students and with their lecturer in the classroom [29], [10], [11]. Learning performance in this research was related to student's academic achievement [34]. Lastly, internet slack was an internet abuse activities which did not comply with the learning objective [1], [8].

This research used several indicators to measure the variables research stated in questionaire as an instrument. Instrument measurement uses a 1-5 Likert scale which is started from strongly disagree to strongly agree. To develop an instrument for social presence, this research adapted indicators from Wei et al. [34]. Wei et al. developed Social Presence (SP) based on social presence indicators, namely: co-presence, intimacy, and immediacy. The indicators used in this research were:

1. CP1: I feel like having others with me in the classroom.

2. CP2: I am aware of others' presence in the classroom.

3. CP3: I feel others close to me in the classroom.

4. CP4: I feel not alone in the classroom.

5. IN1: I have a warm and comfortable relationship with others in the classroom. 
6. IN2: I receive considerable emotional support from others in the classroom.

7. IN3: I feel emotionally close to others in the classroom.

8. IM1: I find myself respected by others in the classroom.

9. IM2: I find myself encouraged by others in the classroom.

10. IM3: I find myself assisted by others in the classroom.

11. IM4: I find myself treated fairly by others in the classroom.

Kozuh et al. [10] argues that social interaction had positive impact to the academic success. In the research, the instrument developed to measure Social Interaction (SI) was from Wei et al. [34]. Specifically, Wei et al. has placed social interaction in learning context, so the indicators used were:

1. SI1: I often discuss learning issues with others in the classroom.

2. SI2: I often share learning materials or opinions with others in the classroom.

3. SI3: I often talk about learning goals and tasks with others in the classroom.

4. SI4: I am happy to answer others' learning questions in the classroom.

To measure Learning Performance (LP), this research adopted from Wei et al. [34]. Clearly, Wei et al. [34] shows indicators to measure this variable, namely

1. LP1: I always finish the assignments of the course.

2. LP2: I achieve the learning goals of the course.

3. LP3: I learn valuable knowledge in the course.

4. LP4: I get a good grade in the course.

Research of internet slack had been conducted by Gerow et al. [1] and Galluch and Thatcher [8]. This research developed the indicator measurement of Internet Slack (ISL) from their research. The indicators are:

1. ISL1: I use the Internet for non-class related purposes during classroom.

2. ISL2: I intend to use the Internet for entertainment during classroom.

3. ISL3: I like to use the Internet to do something other than class-related.

\subsection{Analysis Method}

Analysis method used in this study was Partial Least Square (PLS). This study used WarpPLS 5.0 to execute PLS. Generally, Partial Least Square (PLS) is very suitable for predicting application and theory building, analyzing small samples, and testing the overal fit model with others. PLS has more advantages than the ordinary regression because PLS could test multiple variables simultaneously. WarpPLS 5.0 was used because it had several advantages among other softwares. This software is able to examine the relationship moderating variables directly. On the other side, WarpPLS 5.0 can repair the data, so the normal data can be obtained and processed.

\subsection{Reliability and Validity Testing}

Reliability testing was done to ensure that the research instruments used could present the concept of measurement consistently without any bias [35]. The results obtained could be considered to be consistent if multiple measurements on the same subject obtained different results. In WarpPls 5.0, variables could be considered to be reliable if it had Composite Reliability above 0.60 [36].

Validity testing, according to Hartono [35], shows that the instrument actually measures what it was supposed to measure. The validity of this research was an instrument test to measure that its purpose substantially correct. There were two validity tests, convergent validity and discriminant validity. Convergent validity was tested using loadings factor criteria that should be a significant at a value more than 0.70 and the value of Average Variance Extracted (AVE) for each construct was more than 0.50 .

Discriminant validity had a principle that every indicator in the same construct should have a high correlation compared to the other constructs. The parameters that measured by comparing the root of the AVE of a construct should be higher than the correlation between the other latent variables by looking at the cross loading [36]. 
Tests on the whole model were also conducted. Tests were conducted to look at the overall model. The value used as the indicator standard had to meet the fit model criteria. The fit model criteria were Average Path Coefficient (APC), Average R-squared (ARS), Average Variance Inflation Factor (AVIF), and Variance Inflation Factor (VIF). APC and ARS were significantly at $p$ value under 0.05. The value of AVIF was under 5 and the full value collinearity or VIF was under 3.3 [36].

\subsection{Hypothesis Testing}

The confidence level used in this research was 5\%. The hypothesis would be accepted if the value of $p$ was under $0.05(\mathrm{p}<0.05)$. Path coefficient was used to determine the relationship direction of effect coefficient. The positive effect coefficient indicated that there was a positive relationship between the constructs or variables.

\section{Result and Discussion}

\subsection{Descriptive Statistic}

There were 224 questionnaires distributed to the students. After processed, eight questionnaires were dropped because of incompleteness, so there were 216 questionnaires processed. The data showed that $57,8 \%$ students had GPA scores above three and 42,2\% students had GPA scores under three. The other information captured showed that there were 169 students who had three years study period, 37 students who had four years study period, and 10 students who had study period more than five years. These information showed that respondents in this research had a good experience in the learning process and learning style.

\subsection{Reliability and Validity Test}

To test the reliability of the instrument, WarpPls 5.0 used composite reliability. The composite reliability score needed was above 0.6 for every variable. Calculation of composite reliability is presented in Table 1. Note that ISL: Internet Slack, SP: Social Presence, SI: Social Interaction, LP: Learning Performance.

Table 1. Reliability Testing

\begin{tabular}{ccc}
\hline Variable & Cronbach's alpha & Composite reliability \\
\hline ISL & 0.797 & 0.881 \\
SP & 0.870 & 0.903 \\
SI & 0.818 & 0.880 \\
LP & 0.772 & 0.868 \\
ISL*SP & 0.937 & 0.944 \\
ISL*SI & 0.899 & 0.916 \\
\hline
\end{tabular}

It can be concluded that, from Table 1 every variable value in cronbach's alpha and composite reliability shown is higher than 0,50 . It means that variables used in this model meet the reliability indicator.

Validity test in WarpPls 5.0 is based on loadings factor that must achieve more than 0.7 in every indicator item. Loading factor calculation from warpPls 5.0 can be seen in Table 2 .

Table 2. Discriminant Validity Testing

\begin{tabular}{clcc}
\hline Variable & Indicator & Loading & P-Values \\
\hline \multirow{2}{*}{ ISL } & ISL1 & 0.810 & $<0.001$ \\
& ISL2 & 0.869 & $<0.001$ \\
& ISL3 & 0.851 & $<0.001$ \\
& IN1 & 0.840 & $<0.001$ \\
SP & IN2 & 0.832 & $<0.001$ \\
& IN3 & 0.865 & $<0.001$ \\
& IM1 & 0.747 & $<0.001$
\end{tabular}




\begin{tabular}{clcc}
\hline Variable & Indicator & Loading & P-Values \\
\hline \multirow{6}{*}{} & IM2 & 0.711 & $<0.001$ \\
& CP3 & 0.672 & $<0.001$ \\
SI & LI1 & 0.818 & $<0.001$ \\
& LI2 & 0.833 & $<0.001$ \\
& LI3 & 0.840 & $<0.001$ \\
& LI4 & 0.725 & $<0.001$ \\
& LP2 & 0.853 & $<0.001$ \\
LP & LP3 & 0.808 & $<0.001$ \\
& LP4 & 0.826 & $<0.001$ \\
\hline
\end{tabular}

Table 2 shows the discriminant validity of variable. Value that usually needs to measure discriminant validity is 0,70 [36]. Values in Table 2 were obtained after several indicators dropped because the values were under 0.70. The indicators dropped were CP1 (0.471), CP2 (0.619), CP4 (0.654), IM3 (0.659), M4 (0.605), and LP1 (0.547). Reducing these indicators increased the AVE's value. It means that these indicators have no meaning and should be removed [36]. However, the indicator CP3 (0.672) was still used because, if this indicator was dropped, it had an effect on reducing AVE's values. It means that the indicators have an effect in the model and should be kept. Hence, all of indicators in this research still meet the discriminant validity and can be used.

To measure convergent validity, average variance extracted (AVE) was used. The values used to measure convergent validity for every variable were above 0.50 . The values of AVE are presented in Table 3.

Table 3. Convergent Validity Testing

\begin{tabular}{ccc}
\hline Variable construct & AVE & Square roots of AVE \\
\hline ISL & 0.712 & 0.844 \\
SP & 0.610 & 0.781 \\
SI & 0.648 & 0.805 \\
LP & 0.559 & 0.748 \\
\hline
\end{tabular}

From Table 3, it can be seen that all of the values in every variable was above 0.50 , so variables used in this research fulfill the convergent validity criteria. Based on Table 1, 2, and 3, it can be concluded that variables in this research meet the reliability and validity criteria.

\subsection{Model Measurement}

The benefit of using WarpPls 5.0 is that WarpPls 5.0 provides an indicator criterion to test the fit model proposed in the research. The indicators used were APC, ARS, VIF, and AVIF. The calculation of fit model can be seen in the Table 4 .

Table 4. Fit Model Measurement

\begin{tabular}{ccc}
\hline Indicators & Calculation Result & Ideal \\
\hline APC & 0.003 & $<0.05$ \\
ARS & $<0.001$ & $<0.05$ \\
VIF & 1.698 & $<3.3$ \\
AVIF & 1.472 & $<3.3$ \\
\hline
\end{tabular}

From Table 4, it can be known that all of the fit model indicators have fulfill the fit model criteria. From the output in Table 4, the research model proposed in this research is good enough.

\subsection{Hypothesis Testing}

After reliability and validity testing were met, hypothesis testing was conducted. In WarpPls 5.0, Hypothesis testing used p-values as an indicator. If the value of $p$-value was under or lower than 0.05 , hypothesis would be accepted. The results of hypotheses testing are presented in Table 5. 
Table 5. Hypothesis Testing

\begin{tabular}{lcccc}
\hline \multicolumn{2}{c}{ Hypothesis } & Path coefficients & P values & Result \\
\hline H1 & SP*LP & 0.337 & $<0.001$ & Supported \\
H2 & SI*LP & 0.186 & 0.003 & Supported \\
H3 & ISL*SP*LP & 0.017 & 0.404 & Not Supported \\
H4 & ISL*SI*LP & 0.125 & 0.031 & Not Supported \\
\hline
\end{tabular}

The results of hypothesis testing show that $\mathrm{H} 1$ and $\mathrm{H} 2$ are supported because these p-values were under 0.05 , while $\mathrm{H} 3$ is not supported because these $\mathrm{p}$-values were higher than 0.05 . P-values of $\mathrm{H} 4$ is under the 0.05 but $\mathrm{H} 4$ is not supported because the path coefficient shows the positive effect, meanwhile the hypothesis made in this study is negative effect for $\mathrm{H} 4$. The whole testing model is shown in the figure 2.

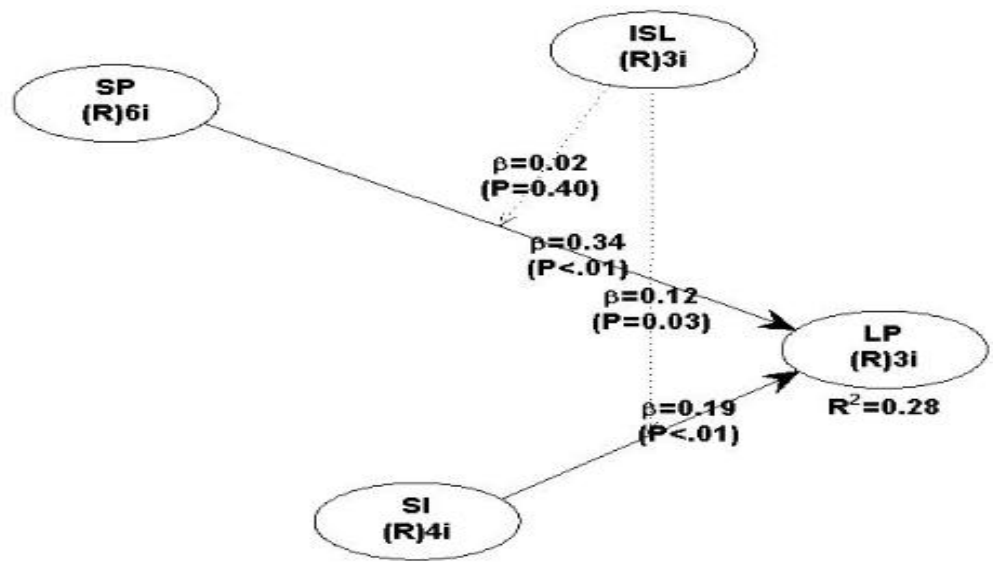

Figure 2. Research Model Testing

These finding indicates that social presence and social interaction have an important role to increase the learning performance. This finding is supported by research conducted by Kozuh et al. [10] and Wei et al. [34]. R square in this model was 0.28. It means that independent variable can explain the dependent variable as $28 \%$. There are still $72 \%$ of other variables that may influence the learning performance. Data shown in Table 5 and Figure 1 show that internet slack is not the variable of moderating that affect the relation between social presence and learning performance toward learning performance. Results from hypotheses testing above indicate that internet slack activity may not disturb the learning activity.

\subsection{Discussion}

This study was done in the hybrid classroom in which learning activity was held in conventional way but students were allowed to open their gadgets to access information from the internet. Teacher also used internet to send the material through e-learning web site. E-book was also given to help the students in the learning activity. Using internet in class helps the students to get information faster and teacher can maximize learning activity in the classroom with various manners [19], [1]. The results of this study show that internet slack has no effect on learning process. This study shows that the internet slack has no bad influence on the effect of social interaction to learning performance. This finding shows that the internet is just a media of learning. The importance factor of the learning process is the student motivation [1]. The motivation of learning can push the student to pay attention to the course material and teacher. Internet slack is not the only one factor that disturbs the interaction between student and teacher. Learning style and the student needs can be the factors that make the effective interaction in the classroom [37]. Supported by internet self-efficacy and cognitive absorption of the student, internet can be the new way of learning [8], [1], [38]. The abilities of the students to use the 
internet, such as internet self-efficacy and cognitive absorption, and a new learning style can increase the role of the internet as educational media [38].

The second result in this study is that internet slack has no effect on the relation between social presence and learning performance. It means that students felt and realized the classroom situation but on the other side, due to the finding, they did not involve deeply on learning activities. It may happen because of multitasking activity facilitated by the gadget [8]. Internet also facilitates them to do multitasking activity. Research done by Gerow et al. [1] clearly shows that cognitive absorption and the ability to be multitasking, positively affect internet slack activities. This ability enables the students to enjoy the internet while in the same time they join the classroom activities. However, the consequences of multitasking activity is that students do not pay attention fully. It can be seen from the finding that internet may disturb interaction in the classroom.

\section{Conclusion}

This study aims to evaluate the effect of internet slack to the learning performance. From this study, it can be concluded that students' learning performance is affected by social presence and social interaction. However, internet slack has no effect on the social presence and internet slack is not the factor that disturb the interaction in the classroom. From the finding, it can be inferred that using internet as a learning media can be used in the hybrid classroom.

Internet may not be appropriate for every student because everyone has his or her own learning style [37], but finding the new e-learning concept is more important than the learning tools. Learning design plays a significant role in the e-learning environment to support and control the student activity [38], [1], [16]. With a clear rule and purpose, the internet can support the learning process so learning activity can be done efficiently and effectively. Besides controlling the hybrid learning process, elearning should accommodate the need to interact each other in the new way. This research finding indicates that interaction is important for learning performance so web 2.0 and web 3.0 technologies can be adopted so interaction can be facilitated in e-learning.

There are limitations in this research. First, this research finding shows that there is a low value for R2. R2 for learning performance only explains $28 \%$, it means that there are still many factors that can affect the learning performance. However, this research only uses two independent factors explaining learning performance. This research also focuses on the impact of internet slack in the classroom. Two independent variables used in this research, basically, are the factors influencing learning performance in the conventional learning. This research wants to examine the impact of internet slack to those factors and learning performance.

Second, this research uses hybrid classroom, combining conventional learning and e-learning in the classroom, as the sample. This study does not apply different treatment on the sample class used. This condition makes a complex activity in the classroom. The future research can compare the hybrid learning activity with different condition. One class uses internet without specific rule and another class uses internet with specific rule as a control. Through this way, the result can manifest the real impact of internet slack. Control can be the factor that makes different result in the learning activity [1].

\section{References}

[1] J. E. Gerow, P. S. Galluch, and J. B. Thatcher, "To Slack or Not to Slack: Internet Usage in the Classroom," JITTA J. Inf. Technol. Theory Appl., vol. 11, no. 3, pp. 5-23, 2010.

[2] J. B. Arbaugh, "Virtual Classroom versus Physical Classroom: An Exploratory Study of Class Discussion Patterns and Student Learning in an Asynchronous Internet-Based MBA Course," J. Manag. Educ., 2000.

[3] Y. Cao and S. Sakchutchawan, "Online vs. traditional MBA: An Empirical study of students' characteristics, course satisfaction, and overall Success," J. Hum. Resour. Adult Learn., vol. 7, no. 2, pp. 1-12, 2011.

[4] J. Ashby, W. A. Sadera, and S. W. Mcnary, "Comparing student success between 
developmental math courses offered online, blended, and face-to-face. Jean Ashby," $J$. Interact. Online Learn., vol. 10, no. 3, pp. 128-140, 2011.

[5] D. Adams, "Wireless laptops in the classroom (and the Sesame Street syndrome)," Commun. ACM, vol. 49, no. 9, p. 25, 2006.

[6] D. Cole, "Laptops vs. Learning," 2007.

[7] J. R. Young, "The Cat-And-Mouse Game Of Plagiarism Detection: Colleges Provide Professors With New Online Tools To Give Them The Upper Hand," The Chronicle of Higher Education, 2001. .

[8] P. S. Galluch and J. Thatcher, "Maladaptive vs . Faithful Use of Internet Applications in the Classroom: An Empirical Examination," J. Inf. Technol. Theory Appl., vol. 12, no. 1, pp. 5-22, 2011.

[9] M. Bugeja, "Distractions in the wireless classroom," Chron. High. Educ., 2007.

[10] I. Kožuh, Z. Jeremić, A. Sarjaš, J. L. Bele, V. Devedžić, and M. Debevc, "Social Presence and Interaction in Learning Environments : The Effect on Student Success," Educ. Technol. Soc., vol. 18, no. 1, pp. 223-236, 2015.

[11] B. K. Walker, "How Social Interaction, Presence, Social Presence, and Sense of Community Influence Student Learning Experiences in an Online Virtual Environment," 2007.

[12] M. Aparicio, F. Bacao, and T. Oliveira, "An e-Learning Theoritical Framework," Educ. Technol. Soc., vol. 19, no. 1, pp. 292-307, 2016.

[13] F. Biocca, C. Harms, and J. Gregg, "The networked minds measure of social presence: Pilot test of the factor structure and concurrent validity," 2001.

[14] F. Biocca, C. Harms, and J. K. Burgoon, "Toward a More Robust Theory and Measure of Social Presence: Review and Suggested Criteria," in Presence: Teleoperators and Virtual Environments, 2003.

[15] C.-H. Tu, "How Chinese Perceive Social Presence: An Examination of Interaction in Online Learning Environment," EMI. Educ. Media Int., vol. 38, no. 1, pp. 45-60, 2002.

[16] E. B. Parker, J. Short, E. Williams, and B. Christie, "The Social Psychology of Telecommunications.," Contemp. Sociol., vol. 7, no. 1, p. 32, 2006.

[17] E. L. Sallnäs, "Effects of communication mode on social presence, virtual presence, and performance in collaborative virtual environments," Presence Teleoperators Virtual Environ., vol. 14, no. 4, pp. 434-449, 2005.

[18] P. Lowenthal and B. G. Wilson, "Labels do matter! a critique of AECT's redefinition of the field," TechTrends, vol. 54, no. 1, pp. 38-46, 2010.

[19] G. Cui, B. Lockee, and C. Meng, "Building modern online social presence: A review of social presence theory and its instructional design implications for future trends," Educ. Inf. Technol., vol. 18, no. 4, pp. 661-685, 2013.

[20] J. R. Young, "The Fight for Classroom Attention: Professor vs. Laptop," Chron. High. Educ., vol. 52, no. 39, pp. A27-A29, 2006.

[21] Q. Zhang and J. G. Oetzel, "Constructing and validating a teacher immediacy scale: A Chinese perspective," Commun. Educ., vol. 55, no. 2, pp. 218-241, 2006.

[22] A. G. Picciano, "Beyond student perceptions: Issues of interaction, presence, and performance in an online course," J. Asynchronous Learn. Netw., vol. 6, no. 1, 2002.

[23] J. C. Richardson and K. Swan, "Examining social presence in online courses in relation to students' perceived learning and satisfaction," J. Asynchronous Learn. Netw., vol. 7, no. 1, 2003.

[24] K. Swan and L. F. Shih, "ON THE NATURE AND DEVELOPMENT OF SOCIAL PRESENCE IN ONLINE COURSE DISCUSSIONS," Online Learn., vol. 9, no. 3, 2019.

[25] S. A. Annie Jin, "Parasocial interaction with an avatar in second life: A typology of the self and an empirical test of the mediating role of social presence," Presence Teleoperators Virtual Environ., vol. 19, no. 4, pp. 331-340, 2010.

[26] D. R. Garrison, M. Cleveland-Innes, and T. S. Fung, "Exploring causal relationships among 
teaching, cognitive and social presence: Student perceptions of the community of inquiry framework," Internet High. Educ., vol. 13, no. 1-2, pp. 31-36, 2010.

[27] F. Ke, "Examining online teaching, cognitive, and social presence for adult students," Comput. Educ., vol. 55, no. 2, pp. 808-820, 2010.

[28] D. R. Garrison, T. Anderson, and W. Archer, "Critical Inquiry in a Text-Based Environment: Computer Conferencing in Higher Education," Internet High. Educ., vol. 2, no. 2-3, pp. 87105, 1999.

[29] T. Erickson and W. A. Kellogg, "Social translucence: an approach to designing systems that support social processes," ACM Trans. Comput. Interact., vol. 7, no. 1, pp. 59-83, 2000.

[30] C. Hostetter and M. Bush, "Measuring Up Online: The Relationship between Social Presence and Student Learning Satisfaction," J. Scholarsh. Teach. Learn., vol. 6, no. 2, pp. 1-12, 2006.

[31] M. F. Beaudoin, "Learning or lurking? Tracking the 'invisible' online student," Internet High. Educ., vol. 5, no. 2, pp. 147-155, 2002.

[32] J. B. Arbaugh and R. Benbunan-Fich, "The importance of participant interaction in online environments," Decis. Support Syst., vol. 43, no. 3, pp. 853-865, 2007.

[33] J. A. A. Lavoie and T. A. Pychyl, "Cyberslacking and the procrastination superhighway: A web-based survey of online procrastination, attitudes, and emotion," Soc. Sci. Comput. Rev., vol. 19, no. 4, pp. 431-444, 2001.

[34] C. W. Wei, N. S. Chen, and Kinshuk, "A model for social presence in online classrooms," Educ. Technol. Res. Dev., vol. 60, no. 3, pp. 529-545, 2012.

[35] J. Hartono, Metodologi Penelitian Sistem Informasi. Yogyakarta: Andi Publisher, 2008.

[36] M. Sholihin and D. Ratmono, Analisis SEM-PLS dengan WarpPLS 3.0 untuk Hubungan Nonlinear dalam Penelitian Sosial dan Bisnis, Penerbit Andi Yogyakarta. 2013. Yogyakarta: Andi Publisher, 2013.

[37] H. Kauffman, "A review of predictive factors of student success in and satisfaction with online learning," Res. Learn. Technol., vol. 23, 2015.

[38] T. Buchanan, S. Joban, and A. Porter, "Internet self-efficacy does not predict student use of Internet-mediated educational technology," Res. Learn. Technol., vol. 22, 2014. 